\title{
Heavy metal chelator TPEN attenuates fura-2 fluorescence changes induced by cadmium, mercury and methylmercury
}

\author{
Masato OHKUBO ${ }^{1)}$, Atsushi MIYAMOTO ${ }^{1)}$ and Mitsuya SHIRAISHI ${ }^{1) *}$ \\ ${ }^{1)}$ Department of Veterinary Pharmacology, Joint Faculty of Veterinary Medicine, Kagoshima University, 1-21-24 Korimoto, Kagoshima \\ 890-0065, Japan
}

(Received 29 October 2015/Accepted 28 December 2015/Published online in J-STAGE 15 January 2016)

ABSTRACT. Stimulation with heavy metals is known to induce calcium $\left(\mathrm{Ca}^{2+}\right)$ mobilization in many cell types. Interference with the measurement of intracellular $\mathrm{Ca}^{2+}$ concentration by the heavy metals in cells loaded with $\mathrm{Ca}^{2+}$ indicator fura- 2 is an ongoing problem. In this study, we analyzed the effect of heavy metals on the fura-2 fluorescence ratio in human SH-SY5Y neuroblastoma cells by using TPEN, a specific cell-permeable heavy metal chelator. Manganese chloride (30-300 $\mu \mathrm{M})$ did not cause significant changes in the fura-2 fluorescence ratio. A high concentration $(300 \mu \mathrm{M})$ of lead acetate induced a slight elevation in the fura-2 fluorescence ratio. In contrast, stimulation with cadmium chloride, mercury chloride or $\mathrm{MeHg}(3-30 \mu \mathrm{M})$ elicited an apparent elevation of the fura-2 fluorescence ratio in a dose-dependent manner. In cells stimulated with 10 or $30 \mu \mathrm{M}$ cadmium chloride, the addition of TPEN decreased the elevated fura- 2 fluorescence ratio to basal levels. In cells stimulated with mercury or $\mathrm{MeHg}$, the addition of TPEN significantly decreased the elevation of the fura- 2 fluorescence ratio induced by lower concentrations $(10 \mu \mathrm{M})$ of mercury or $\mathrm{MeHg}$, but not by higher concentrations $(30 \mu \mathrm{M})$. Pretreatment with $\mathrm{Ca}^{2+}$ channel blockers, such as verapamil, 2-APB or lanthanum chloride, resulted in different effects on the fura-2 fluorescence ratio. Our study provides a characterization of the effects of several heavy metals on the mobilization of divalent cations and the toxicity of heavy metals to neuronal cells.

KEY WORDS: Fura-2, heavy metal, SH-SY5Y, TPEN

doi: 10.1292/jvms.15-0620; J. Vet. Med. Sci. 78(5): 761-767, 2016

Heavy metals are distributed as environmental pollutants, and human and animal exposure to excessive levels of heavy metals is a global public health problem. Although some heavy metals, such as copper $\left(\mathrm{Cu}^{2+}\right)$, zinc $\left(\mathrm{Zn}^{2+}\right)$, manganese $\left(\mathrm{Mn}^{2+}\right)$ and iron $\left(\mathrm{Fe}^{2+}\right)$, are essential for maintaining normal physiological functions, they can lead to poisoning at higher concentrations. Other metals, including mercury $\left(\mathrm{Hg}^{2+}\right)$, cadmium $\left(\mathrm{Cd}^{2+}\right)$ and lead $\left(\mathrm{Pb}^{2+}\right)$, are not considered essential for biological functions. Exposure to both essential and nonessential heavy metals through inhalation or ingestion of contaminated food and water is known to induce abnormal alterations in the central nervous system, liver, kidneys and hematopoietic system, thus presenting a significant health hazard [18, 20].

Calcium $\left(\mathrm{Ca}^{2+}\right)$ is a highly versatile intracellular signaling molecule that regulates many cellular processes, such as gene transcription, cell motility, exocytosis, cell growth and cell death $[4,41]$. Although the antagonizing effect of heavy metals on $\mathrm{Ca}^{2+}$ channels has been demonstrated [24, 29], stimulation with heavy metals can induce an increase in intracellular calcium concentrations $\left(\left[\mathrm{Ca}^{2+}\right]_{\mathrm{i}}\right)$ in neuronal cells. An increase in $\left[\mathrm{Ca}^{2+}\right]_{i}$ has been reported as induced

\footnotetext{
*Correspondence to: Shiraishi, M., Department of Veterinary Pharmacology, Joint Faculty of Veterinary Medicine, Kagoshima University, 1-21-24 Korimoto, Kagoshima 890-0065, Japan.

e-mail: shira-m@vet.kagoshima-u.ac.jp

(C)2016 The Japanese Society of Veterinary Science

This is an open-access article distributed under the terms of the Creative Commons Attribution Non-Commercial No Derivatives (by-nc-nd) License $<$ http://creativecommons.org/licenses/by-nc-nd/4.0/>.
}

by cadmium in cerebral cortical neurons [40], cerebellar granule neurons [25] and a neuronal cell line [35], by methylmercury $(\mathrm{MeHg})$ in rat cerebellar slices [39], a neuronal cell line [13-15] and cerebellar neurons [9, 23, 26, 30], by mercury in cortical neurons [36], by manganese in cerebellar neurons [37] and by lead in rat hippocampal neurons [10]. Therefore, the disturbance of $\mathrm{Ca}^{2+}$ homeostasis is believed to be involved in the toxicity of heavy metals.

BAPTA-based fluorescent calcium indicators, such as fura-2 and fluo-3, are widely used for measuring $\left[\mathrm{Ca}^{2+}\right]_{\mathrm{i}}$. However, some heavy metals can bind to the fluorescent calcium indicators and change their fluorescence excitation spectra. For example, $\mathrm{Cd}^{2+}$ can bind to fura- 2 with an extremely high affinity, activating spectral responses similar to $\mathrm{Ca}^{2+}[17,21] . \mathrm{Zn}^{2+}, \mathrm{Pb}^{2+}$, strontium $\left(\mathrm{Sr}^{2+}\right)$, barium $\left(\mathrm{Ba}^{2+}\right)$ and lanthanum $\left(\mathrm{La}^{3+}\right)$ are also known to elicit changes of spectra similar to the $\mathrm{Ca}^{2+}$ complex $[2,33]$. In contrast, $\mathrm{Cu}^{2+}$, $\mathrm{Fe}^{2+}$, nickel $\left(\mathrm{Ni}^{2+}\right)$, cobalt $\left(\mathrm{Co}^{2+}\right)$ and $\mathrm{Mn}^{2+}$ are known to quench the fluorescent signal of fura-2 [12, 19, 21], while $\mathrm{Hg}^{2+}$ is believed to have no effect on fura-2 spectra [21]. These reports suggest that endogenous and exogenous heavy metals may interfere with the measurement of $\left[\mathrm{Ca}^{2+}\right]_{\mathrm{i}}$ using fura-2, and this potential problem makes it difficult to analyze the precise effect of heavy metals on $\left[\mathrm{Ca}^{2+}\right]_{i}$.

In this study, we analyzed the effect and contribution of several heavy metals on $\left[\mathrm{Ca}^{2+}\right]_{\mathrm{i}}$ measurement in human neuroblastoma SH-SY5Y cells loaded with fura-2 in the presence of tetrakis-(2-pyridylmethyl) ethylenediamine (TPEN), which is a specific cell-permeable heavy metal chelator. In addition, we examined the effects of $\mathrm{Ca}^{2+}$ channel blockers, such as verapamil, 2-Aminoethoxydiphenyl borate (2-APB) 
and lanthanum chloride, on changes in the fura-2 fluorescence ratio induced by heavy metals.

\section{MATERIALS AND METHODS}

Cell culture: Human neuroblastoma cell line SH-SY5Y (ATCC, Manassas, VA, U.S.A.), were grown in Dulbecco's Modified Eagle's Medium (DMEM) mixed 1:1 with Ham's F-12 nutrient mixture (Sigma-Aldrich, St. Louis, MO, U.S.A.) containing $10 \%$ fetal bovine serum, 100 unit $/ \mathrm{m} l$ penicillin and $100 \mu \mathrm{g} / \mathrm{m} l$ streptomycin at $37^{\circ} \mathrm{C}$ in a humidified $5 \% \mathrm{CO}_{2}$ atmosphere. Two days before experimentation, cells were seeded at a density of $7 \times 10^{4}$ cells $/ \mathrm{cm}^{2}$ in a 96well plate.

Measurement of fura-2 fluorescence changes: Cells in a 96-well plate were serum-starved for $4 \mathrm{hr}$; calcium indicator fura-2 was then loaded into the cells by using Calcium kit II fura-2 (Dojindo Laboratories, Kumamoto, Japan) according to the manufacturer's instructions. In brief, SH-SY5Y cells were incubated with $5 \mu \mathrm{M}$ fura-2/AM in the presence of $0.04 \%$ Pluronic F-127, a dispersing agent to improve the efficiency of loading with fura-2, and $1.25 \mathrm{mM}$ probenecid, a blocker of organic anion transport to prevent leakage of fura-2 from cells [8]. After $1 \mathrm{hr}$ incubation at $37^{\circ} \mathrm{C}$, fura- 2 fluorescence was measured at $500 \mathrm{~nm}$ emission after excitation at $340 \mathrm{~nm}(\mathrm{~F} 340)$ or $380 \mathrm{~nm}$ (F380) using an Infinite M200 plate reader (Tecan, Männedorf, Switzerland) at $37^{\circ} \mathrm{C}$. The change in $\left[\mathrm{Ca}^{2+}\right]_{\mathrm{i}}$ was reflected by the ratio of $\mathrm{F} 340$ and F380. To determine the changes in fura-2 fluorescence ratio induced by heavy metal compounds, cells were treated with manganese chloride (Sigma-Aldrich), lead acetate (Wako, Osaka, Japan), cadmium chloride (Kanto Chemical, Tokyo, Japan), mercuric chloride (Wako) and MeHg chloride (Kanto Chemical) dissolved in distilled water. We confirmed that the cells adhered to the bottom of the plate after $6 \mathrm{hr}$ exposure to heavy metal compounds. The cells were also treated with three $\mathrm{Ca}^{2+}$ channel blockers, lanthanum chloride (Wako) dissolved in distilled water, verapamil (Sigma-Aldrich) and 2-APB dissolved in DMSO, $30 \mathrm{~min}$ before heavy metal exposure. The heavy metal chelator TPEN was dissolved in DMSO and added $3 \mathrm{hr}$ after the stimulation with heavy metals to determine the contribution of endogenous and exogenous heavy metals on fura- 2 fluorescence changes. We measured the effect of TPEN $(20 \mu \mathrm{M})$ on the fura-2 fluorescence ratio after a 10 min treatment with TPEN, since our preliminary experiments showed that the effect of TPEN on fura-2 fluorescence reached maximum and stabilized within 10 min of the treatment.

Data analysis: Results are expressed as the mean \pm SEM. Differences between means were evaluated by Student's $t$-test or Bonferroni's correction for multiple comparisons; $P$ values $<0.05$ were considered significant.

\section{RESULTS}

Fura-2 fluorescence changes induced by heavy metals: Figure 1 shows the changes in the fura-2 fluorescence ratio in SH-SY5Y cells by stimulation with manganese chloride, lead acetate, cadmium chloride, mercury chloride or $\mathrm{MeHg}$. In cells without heavy metal stimulation (controls), we did not observe significant changes in the fura- 2 fluorescence ratio within $6 \mathrm{hr}$ under experimental conditions (data not shown). First, we examined the effect of manganese chloride and lead acetate on fura- 2 fluorescence, since these metals are well known to be neurotoxic substances and have been shown to stimulate $\left[\mathrm{Ca}^{2+}\right]_{\mathrm{i}}[31,37]$. Manganese chloride $(30-300 \mu \mathrm{M})$ did not cause a significant change in the fura-2 fluorescence ratio within $6 \mathrm{hr}$ of exposure (Fig. 1A). Although manganese chloride had no effect on the fura-2 fluorescence ratio, we observed that it induced a quenching of fluorescent signals at both F340 and F380 in a dose-dependent manner (data not shown). Lead (30-100 $\mu \mathrm{M})$ did not cause changes in the fura-2 fluorescence ratio (Fig. 1B). However, a higher concentration $(300 \mu \mathrm{M})$ of lead induced a slight but significant elevation in the fura-2 fluorescence ratio. In contrast, stimulation with cadmium chloride, mercury chloride or $\mathrm{MeHg}$ elicited an apparent elevation of the fura-2 fluorescence ratio in a dose-dependent manner (Fig. 1C, 1D and 1E). The peak increase in the fura-2 fluorescence ratio from basal level ( $\Delta$ Ratio $(340 / 380)$ ) was induced by $30 \mu \mathrm{M}$ cadmium chloride $(2.9 \pm 0.1$ at $6 \mathrm{hr}), 30 \mu \mathrm{M}$ mercury chloride $(2.3 \pm 0.4$ at $3 \mathrm{hr})$ and $30 \mu \mathrm{M} \mathrm{MeHg}(3.3 \pm 0.1 \mathrm{at} 4 \mathrm{hr})$. We confirmed that $\mathrm{Ca}^{2+}$ ionophore ionomycin $(3 \mu \mathrm{M})$ induced significant increase in the $\triangle$ Ratio $(340 / 380)(0.5 \pm 0.1$ at $3 \mathrm{~min})$.

Effect of TPEN on fura-2 fluorescence changes induced by cadmium chloride, mercury chloride or MeHg: Since we observed an apparent elevation of the fura-2 fluorescence ratio induced by stimulation with cadmium chloride, mercury chloride and MeHg in SH-SY5Y cells, we examined the contribution of heavy metal cations to the increase in the fura-2 fluorescence ratio by using TPEN, a cell-permeable chelator for heavy metal cations with a low affinity for $\mathrm{Ca}^{2+}$ [1]. In cells stimulated with 10 or $30 \mu \mathrm{M}$ cadmium chloride, the addition of TPEN at $3 \mathrm{hr}$ after exposure significantly decreased the elevated fura- 2 fluorescence ratio to the basal levels within $10 \min (119.6 \pm 2.4 \%$ or $109.0 \pm 1.5 \%$ decrease in $\Delta$ Ratio (F340/F380) induced by 10 or $30 \mu \mathrm{M}$ cadmium chloride, respectively), suggesting that a cadmium chloride-induced increase in the fura-2 fluorescence ratio was dependent on an increase in intracellular heavy metal cations but not intracellular $\mathrm{Ca}^{2+}$ (Fig. 2A). We observed that the effect of TPEN on the elevated fura-2 fluorescence ratio induced by $30 \mu \mathrm{M}$ cadmium chloride was dose-dependent $(2.4 \pm 3.4 \%, 69.3 \pm$ $3.5 \%$ or $98.3 \pm 0.5 \%$ decrease in $\Delta$ Ratio (F340/F380) by 5 , 10 or $20 \mu \mathrm{M}$ TPEN, respectively, $\mathrm{n}=4$ ). In mercury chloride or $\mathrm{MeHg}$ treated cells, the addition of TPEN significantly decreased the elevation of $\Delta$ Ratio (F340/F380) induced by a lower concentration $(10 \mu \mathrm{M})$ of mercury chloride (173.7 $\pm 19.4 \%$ decrease in $\Delta$ Ratio (F340/F380)) or MeHg (110.7 $\pm 11.1 \%$ decrease in $\Delta$ Ratio (F340/F380)) (Fig. 2B and 2C). However, although the addition of TPEN partially decreased the elevation of $\Delta$ Ratio (F340/F380) induced by a higher concentration $(30 \mu \mathrm{M})$ of mercury chloride $(44.1 \pm 18.0 \%$ decrease in $\Delta$ Ratio (F340/F380)) or MeHg (34.4 $\pm 15.1 \%$ decrease in $\Delta$ Ratio (F340/F380)), the effect was not significant.

Effect of $\mathrm{Ca}^{2+}$ channel blockers on fura-2 fluorescence 

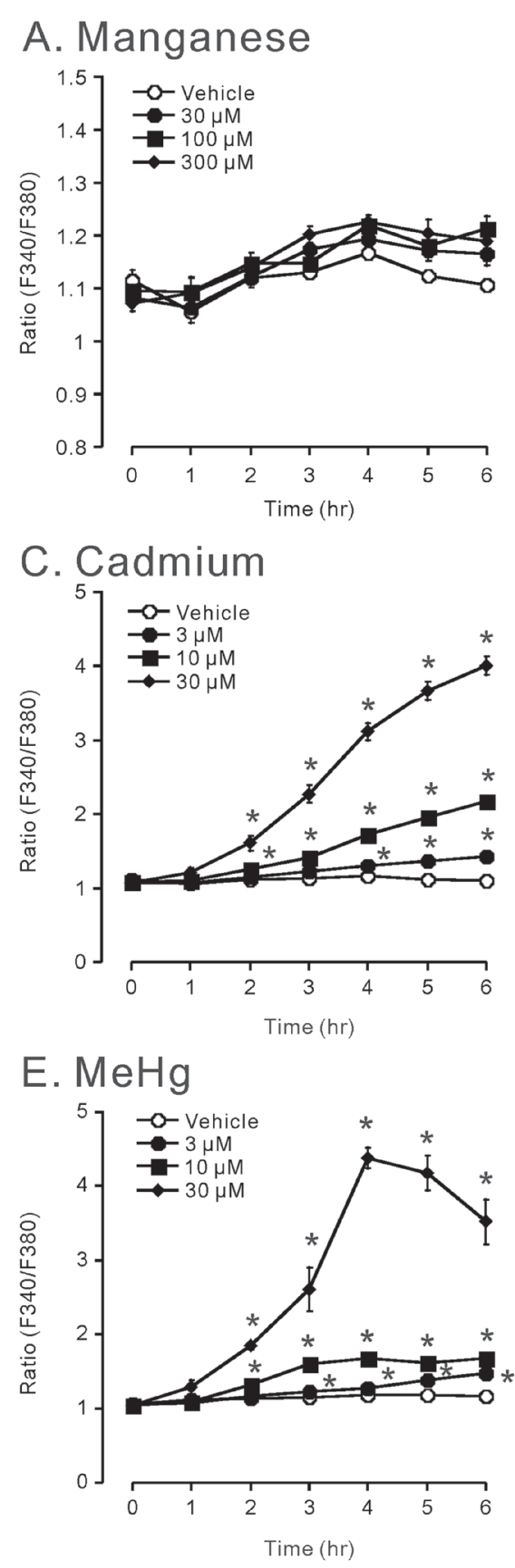

changes induced by cadmium chloride, mercury chloride or $\mathrm{MeHg}$ : Finally, we analyzed the effect of pretreatment with $\mathrm{Ca}^{2+}$ channel blockers on the increase in the fura-2 fluorescence ratio induced by cadmium chloride, mercury chloride or MeHg. Pretreatment with verapamil, an L-type $\mathrm{Ca}^{2+}$ channel blocker [24], or lanthanum chloride, a non-specific cation channel blocker, significantly inhibited the fura-2 fluorescence ratio induced by cadmium chloride (Fig. 3). In contrast, 2-APB, an inositol 1,4,5-trisphosphate $\left(\mathrm{IP}_{3}\right)$ receptor and canonical transient receptor potential cation (TRPC) channel blocker [27], caused only a slight inhibition of the
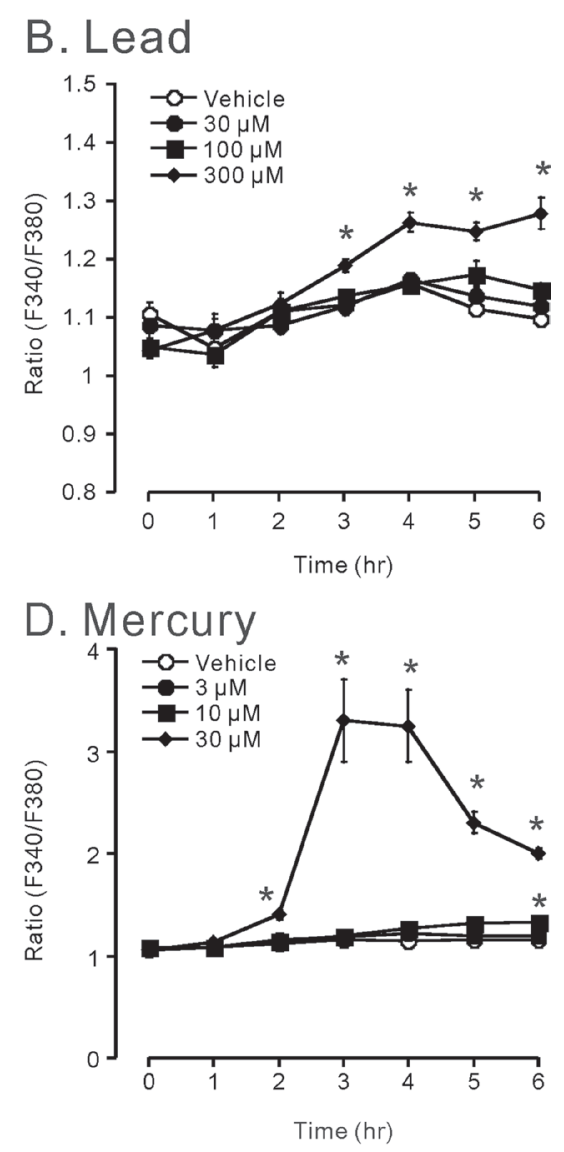

Fig. 1. Fura-2 fluorescence changes induced by stimulation with heavy metals. Fura-2-loaded SH-SY5Y cells were stimulated with (A) manganese chloride (30-300 $\mu \mathrm{M})$, (B) lead acetate (30-300 $\mu \mathrm{M}),(\mathrm{C})$ cadmium chloride (3-30 $\mu \mathrm{M})$, (D) mercury chloride (3-30 $\mu \mathrm{M})$ and (E) $\mathrm{MeHg}(3-30 \mu \mathrm{M})$. The values are expressed as mean \pm SEM $(\mathrm{n}=7)$. $* P<0.05$ vs. control (without stimulation).

cadmium chloride-induced increase in the fura-2 fluorescence ratio. The fura- 2 fluorescence ratio induced by mercury chloride was not affected by treatment with verapamil, 2-APB or lanthanum chloride (Fig. 4). Although verapamil and lanthanum chloride did not cause significant effects, 2-APB significantly suppressed the increase in the fura-2 fluorescence ratio induced by $\mathrm{MeHg}$ (Fig. 5).

\section{DISCUSSION}

Fura-2 is a UV-excited ratiometric indicator dye for mea- 


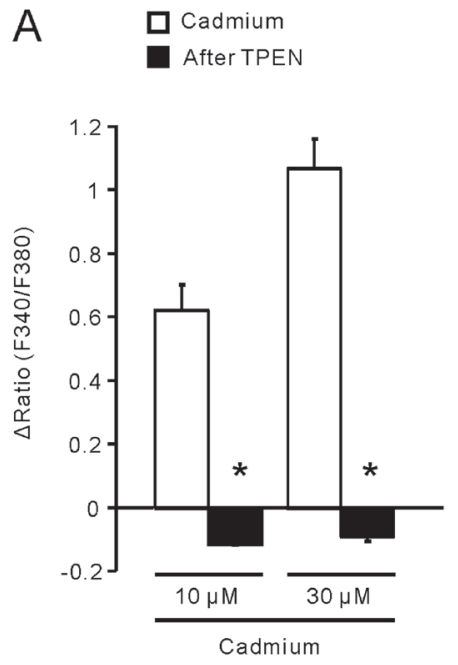

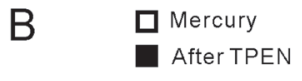

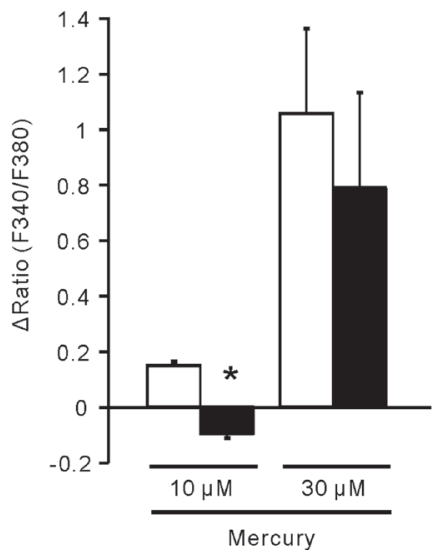

C $\quad \square$ MeHg

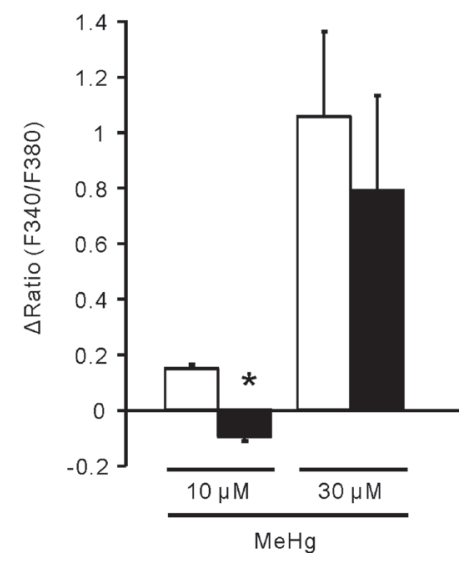

Fig. 2. Effect of TPEN on fura-2 fluorescence changes induced by stimulation with cadmium chloride, mercury chloride or MeHg. Contribution of heavy metal cations to the increase in the fura- 2 fluorescence ratio was estimated by addition of TPEN (20 $\mu \mathrm{M}) 3 \mathrm{hr}$ after stimulation with 10 or $30 \mu \mathrm{M}$ cadmium chloride (A), mercury chloride (B) or MeHg (C) by measurement of $\Delta$ Ratio (F340/F380) before and after the addition of TPEN. The values are expressed as mean $\pm \mathrm{SEM}(\mathrm{n}=8)$. ${ }^{*} P<0.05$ vs. $\triangle$ Ratio $(\mathrm{F} 340 / \mathrm{F} 380)$ before the addition of TPEN.

suring $\left[\mathrm{Ca}^{2+}\right]_{\mathrm{i}}[12]$. Upon binding of fura-2 to $\mathrm{Ca}^{2+}, \mathrm{Cd}^{2+}$, $\mathrm{Pb}^{2+}$ and $\mathrm{Zn}^{2+}$, the emission fluorescence intensity increases at $340 \mathrm{~nm}$ (F340) and decreases at $380 \mathrm{~nm}$ (F380) for the unbound form $[2,17,33]$. This change in fluorescence intensity results in elevation of the fura-2 fluorescence ratio (F340/ F380). In contrast, the binding of fura- 2 to some heavy metals, such as $\mathrm{Mn}^{2+}$ and $\mathrm{Fe}^{2+}$, quenches the fluorescence (both at F340 and F380) $[12,19,21]$. In this study, we found that manganese chloride did not cause significant changes in the fura-2 fluorescence ratio in SH-SY5Y cells. However, we observed a quenching of the fluorescent signal at both F340 and F380. Thus, it is likely that the $\mathrm{Mn}^{2+}$ penetrates cells and quenches the fura-2 fluorescence.

Lead acetate caused a significant increase in the fura-2 fluorescence ratio only at a higher concentration $(300 \mu \mathrm{M})$. Sukumar and Beech (2010) reported that stimulation with low lead acetate concentrations induced an increase in $\left[\mathrm{Ca}^{2+}\right]_{\mathrm{i}}$ through the TRPC5 channel in fura-2-loaded HEK 293 cells with TRPC5 overexpression [29]. Since expression of the TRPC5 channel in SH-SY5Y cells has been suggested [5], TRPC5 might mediated the increase in $\left[\mathrm{Ca}^{2+}\right]_{\mathrm{i}}$ by a higher concentration of lead acetate, while it may not have been enough to induce an apparent increase in the fura-2 fluorescence ratio at lower concentrations.

We found that cadmium chloride, mercury chloride and $\mathrm{MeHg}$ caused an apparent increase in the fura- 2 fluorescence ratio in a dose-dependent manner. Therefore, we analyzed the contribution of endogenous or exogenous metal cations to the fura-2 fluorescence change using TPEN, a cell-permeable chelator for heavy metals. The increase in the fura- 2 fluorescence ratio by stimulation with 10 or $30 \mu \mathrm{M}$ cadmium chloride was inhibited to the basal level by the addition of TPEN, suggesting that the increase in the fura- 2 fluorescence ratio was dependent on heavy metal cations but not intracel- lular $\mathrm{Ca}^{2+}$. Given that $\mathrm{Ca}^{2+}$ channels mediate $\mathrm{Cd}^{2+}$ influx in many cell types [6], it is likely that the change in the fura-2 fluorescence ratio induced by cadmium chloride is caused by an influx of $\mathrm{Cd}^{2+}$, which binds fura-2 with high affinity and activates its spectral responses, as $\mathrm{Ca}^{2+}$ does [17]. In support of this explanation, we observed that verapamil and lanthanum chloride partially inhibited the increase in the fura-2 fluorescence ratio induced by cadmium chloride. Furthermore, Hinkle et al. (1987) reported that verapamil reduced cell death induced by cadmium chloride in a pituitary cell line [16]. On the other hand, cellular uptake of $\mathrm{Cd}^{2+}$ by metal transporters, such as divalent metal transporter 1 (DMT1), Zrt/Irt-related protein (ZIP) 8 and ZIP14, had been reported [32]. Although DMT1 and ZIP14 are expressed in SH-SY5Y cells $[11,34]$, the contribution to the $\mathrm{Cd}^{2+}$ uptake has not been known. The involvement of these metal transporters in the cadmium-induced increase in fura- 2 fluorescence ratio needs to be clarified in future studies.

The addition of TPEN to cells exposed to a low concentration of mercury chloride or $\mathrm{MeHg}(10 \mu \mathrm{M})$ returned the increased fura-2 fluorescence ratio to basal level, while a higher concentration $(30 \mu \mathrm{M})$ of mercury chloride or $\mathrm{MeHg}$ caused an increase in the fura- 2 fluorescence ratio that was only partially sensitive to the TPEN treatment. These results suggest that higher concentrations of mercury chloride and $\mathrm{MeHg}$ induce an increase in the fura-2 fluorescence ratio through an increase in intracellular $\mathrm{Ca}^{2+}$ in SH-SY5Y cells, in addition to the increase in intracellular metal cation levels. Since $\mathrm{Hg}^{2+}$ and $\mathrm{MeHg}$ do not cause perturbation of fura-2 fluorescence $[15,21]$, the increase in the fura-2 fluorescence ratio which was sensitive to treatment with TPEN may be dependent on endogenous metal cation mobilization. A contribution by endogenous $\mathrm{Zn}^{2+}$ mobilization in measurement of $\left[\mathrm{Ca}^{2+}\right]_{\mathrm{i}}$ by fura-2 has been proposed [22], and, in fact, 
A.Verapamil

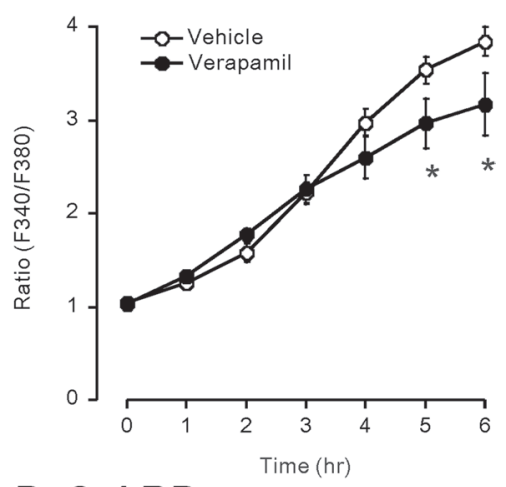

B. 2-APB

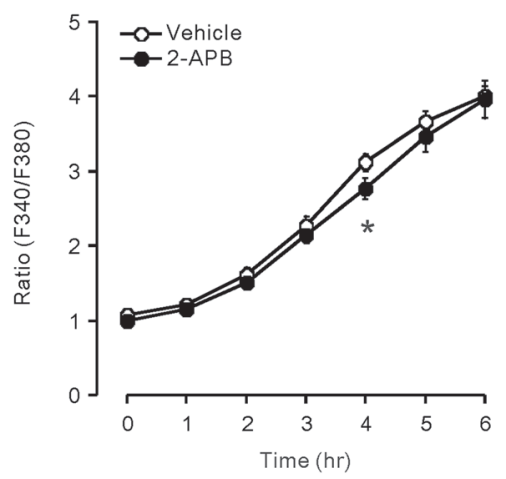

C. Lanthanum

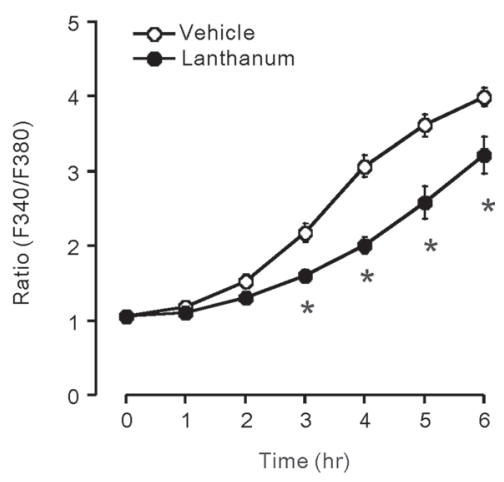

Fig. 3. Effect of $\mathrm{Ca}^{2+}$ channel blockers on fura-2 fluorescence change induced by stimulation with cadmium chloride. Cells were treated with (A) verapamil $(10 \mu \mathrm{M})$, (B) 2-APB $(10 \mu \mathrm{M})$ or $(\mathrm{C})$ lanthanum chloride $(100 \mu \mathrm{M}) 30 \mathrm{~min}$ before stimulation with cadmium chloride $(30 \mu \mathrm{M})$. The values are expressed as mean \pm SEM $(\mathrm{n}=6) .{ }^{*} P<0.05$ vs. vehicle-treated cells.

elevation of $\left[\mathrm{Zn}^{2+}\right]_{\mathrm{i}}$ by MeHg was reported in synaptosomes [7]. Taken together, it is likely that the increase in $\left[\mathrm{Zn}^{2+}\right]_{\mathrm{i}}$, at least in part, contributes to a TPEN-sensitive increase in the fura-2 fluorescence ratio induced by exogenous heavy metals. In contrast with cadmium chloride, a MeHg-induced increase in the fura-2 fluorescence ratio was suppressed by 2 -APB but not by verapamil or lanthanum chloride, although alteration of MeHg-induced $\mathrm{Ca}^{2+}$ mobilization by treatment

\section{A.Verapamil}

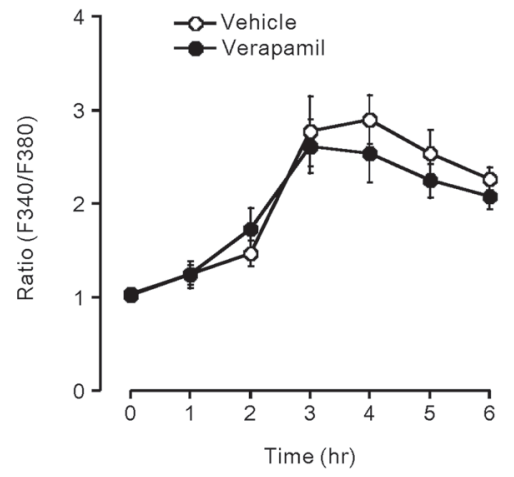

B. 2-APB

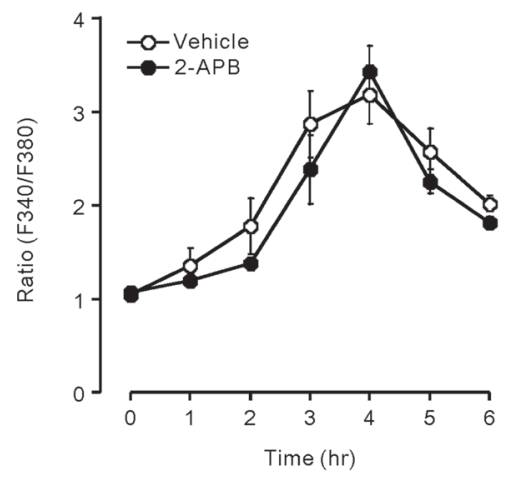

C. Lanthanum

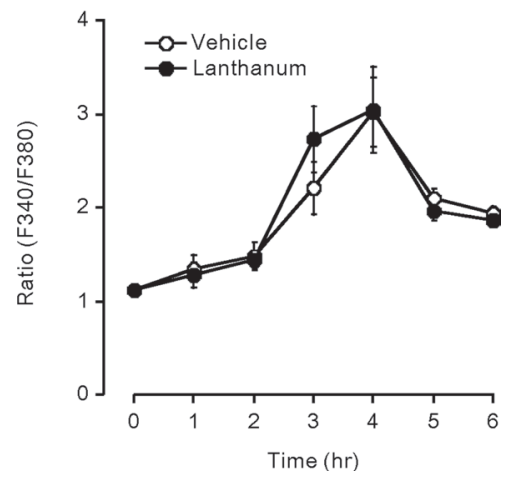

Fig. 4. Effect of $\mathrm{Ca}^{2+}$ channel blockers on fura-2 fluorescence change induced by stimulation with mercury chloride. Cells were treated with (A) verapamil $(10 \mu \mathrm{M})$, (B) 2-APB $(10 \mu \mathrm{M})$ or (C) lanthanum chloride $(100 \mu \mathrm{M}) 30$ min before stimulation with mercury chloride $(30 \mu \mathrm{M})$. The values are expressed as mean \pm SEM $(\mathrm{n}=9) . * P<0.05$ vs. vehicle-treated cells.

with nifedipine, an L-type $\mathrm{Ca}^{2+}$ channel blocker, has been reported in cerebellar granule cells [23], a neuronal cell line $[13,14,23]$ and spinal motor neurons [28]. In agreement with previous reports that $\mathrm{MeHg}$ induced an increase in inositol phosphate levels and activated TRPC channels [14, 30, 38], 2-APB, an $\mathrm{IP}_{3}$ receptor and TRPC channel blocker [27], inhibited an increase in the fura-2 fluorescence ratio induced by MeHg. In this study, significant inhibitory effects were not 


\section{A.Verapamil}

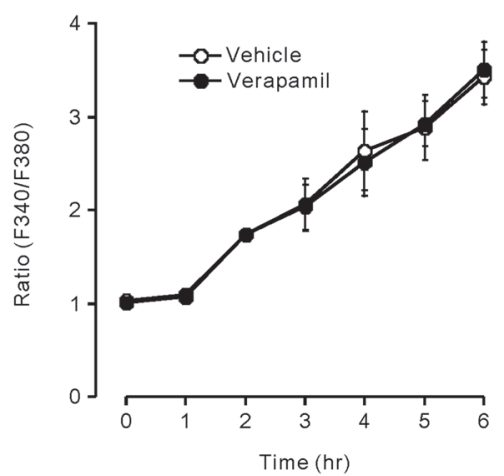

B. 2-APB

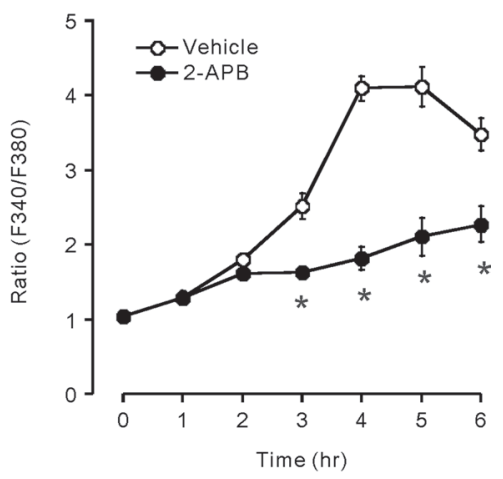

C. Lanthanum

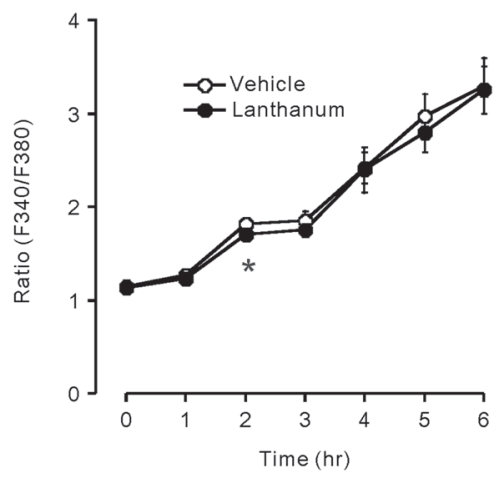

Fig. 5. Effect of $\mathrm{Ca}^{2+}$ channel blockers on fura-2 fluorescence change induced by stimulation with $\mathrm{MeHg}$. Cells were treated with (A) verapamil $(10 \mu \mathrm{M})$, (B) 2-APB $(10 \mu \mathrm{M})$ or (C) lanthanum chloride $(100 \mu \mathrm{M}) 30 \mathrm{~min}$ before stimulation with $\mathrm{MeHg}(30 \mu \mathrm{M})$. The values are expressed as mean $\pm \operatorname{SEM}(\mathrm{n}=9)$. ${ }^{*} P<0.05$ vs. vehicle-treated cells.

observed in mercury chloride-induced increases in the fura2 fluorescence ratio after treatment with verapamil, 2-APB or lanthanum chloride. Recently, Xu et al. (2012) reported that a mercury-induced increase in $\left[\mathrm{Ca}^{2+}\right]_{\mathrm{i}}$ was inhibited by MK801, an antagonist of the NMDA receptor, in cultured cortical neurons [36]. Expression of the NMDA receptor in SH-SY5Y cells has also been reported [3]. The involvement of NMDA receptors or other types of $\mathrm{Ca}^{2+}$ channels, with the mobilization of $\left[\mathrm{Ca}^{2+}\right]_{\mathrm{i}}$ by heavy metals in SH-SY5Y cells remains to be clarified.

In this study, we showed that the elevation of the fura-2 fluorescence ratio is dependent not only on $\mathrm{Ca}^{2+}$ but also on heavy metal cations in SH-SY5Y cells. Furthermore, the contribution of heavy metal cations to the changes in the fura-2 fluorescence ratio induced by exogenous heavy metals was metal- and concentration-specific. Our study provides a characterization of the effects of several heavy metals on the mobilization of divalent cations and the toxicity of heavy metals to neuronal cells.

ACKNOWLEDGMENT. This work was supported by a Grant-in-Aid for Young Scientists (B) (No. 23780298) from the Japan Society for the Promotion of Sciences (JSPS).

\section{REFERENCES}

1. Anderegg, G., Hubmann, E., Podder, N. G. and Wenk, F. 1977. Pyridinderivate als Komplexbildner. XI. Die Thermodynamik der Metallkomplexbildung mit Bis-, Tris- und Tetrakis[(2-pyridyl)methyl]-aminen. Helv. Chim. Acta 60: 123-140. [CrossRef]

2. Atar, D., Backx, P. H., Appel, M. M., Gao, W. D. and Marban, E. 1995. Excitation-transcription coupling mediated by zinc influx through voltage-dependent calcium channels. J. Biol. Chem. 270: 2473-2477. [Medline] [CrossRef]

3. de Arriba, S. G., Krügel, U., Regenthal, R., Vissiennon, Z., Verdaguer, E., Lewerenz, A., García-Jordá, E., Pallas, M., Camins, A., Münch, G., Nieber, K. and Allgaier, C. 2006. Carbonyl stress and NMDA receptor activation contribute to methylglyoxal neurotoxicity. Free Radic. Biol. Med. 40: 779-790. [Medline] [CrossRef]

4. Berridge, M. J., Lipp, P. and Bootman, M. D. 2000. The versatility and universality of calcium signalling. Nat. Rev. Mol. Cell Biol. 1: 11-21. [Medline] [CrossRef]

5. Bollimuntha, S., Singh, B. B., Shavali, S., Sharma, S. K. and Ebadi, M. 2005. TRPC1-mediated inhibition of 1-methyl4-phenylpyridinium ion neurotoxicity in human SH-SY5Y neuroblastoma cells. J. Biol. Chem. 280: 2132-2140. [Medline] [CrossRef]

6. Choong, G., Liu, Y. and Templeton, D. M. 2014. Interplay of calcium and cadmium in mediating cadmium toxicity. Chem. Biol. Interact. 211: 54-65. [Medline] [CrossRef]

7. Denny, M. F. and Atchison, W. D. 1994. Methylmercury-induced elevations in intrasynaptosomal zinc concentrations: an 19FNMR study. J. Neurochem. 63: 383-386. [Medline] [CrossRef]

8. Di Virgilio, F., Steinberg, T. H., Swanson, J. A. and Silverstein, S. C. 1988. Fura-2 secretion and sequestration in macrophages. A blocker of organic anion transport reveals that these processes occur via a membrane transport system for organic anions. $J$. Immunol. 140: 915-920. [Medline]

9. Edwards, J. R., Marty, M. S. and Atchison, W. D. 2005. Comparative sensitivity of rat cerebellar neurons to dysregulation of divalent cation homeostasis and cytotoxicity caused by methylmercury. Toxicol. Appl. Pharmacol. 208: 222-232. [Medline] [CrossRef]

10. Fan, G., Zhou, F., Feng, C., Wu, F., Ye, W., Wang, C., Lin, F., Yan, J., Li, Y., Chen, Y. and Bi, Y. 2013. Lead-induced ER calcium release and inhibitory effects of methionine choline in cultured rat hippocampal neurons. Toxicol. In Vitro 27: 387-395. [Medline] [CrossRef]

11. Fujishiro, H., Yoshida, M., Nakano, Y. and Himeno, S. 2014. 
Interleukin-6 enhances manganese accumulation in SH-SY5Y cells: implications of the up-regulation of ZIP14 and the down-regulation of ZnT10. Metallomics 6: 944-949. [Medline] [CrossRef]

12. Grynkiewicz, G., Poenie, M. and Tsien, R. Y. 1985. A new generation of $\mathrm{Ca}^{2+}$ indicators with greatly improved fluorescence properties. J. Biol. Chem. 260: 3440-3450. [Medline]

13. Hare, M. F. and Atchison, W. D. 1995. Nifedipine and tetrodotoxin delay the onset of methylmercury-induced increase in $\left[\mathrm{Ca}^{2+}\right]_{\mathrm{i}}$ in NG108-15 cells. Toxicol. Appl. Pharmacol. 135: 299-307. [Medline] [CrossRef]

14. Hare, M. F. and Atchison, W. D. 1995. Methylmercury mobilizes $\mathrm{Ca}^{++}$from intracellular stores sensitive to inositol 1,4,5-trisphosphate in NG108-15 cells. J. Pharmacol. Exp. Ther. 272: 1016-1023. [Medline]

15. Hare, M. F., McGinnis, K. M. and Atchison, W. D. 1993. Methylmercury increases intracellular concentrations of $\mathrm{Ca}^{++}$and heavy metals in NG108-15 cells. J. Pharmacol. Exp. Ther. 266: 1626-1635. [Medline]

16. Hinkle, P. M., Kinsella, P. A. and Osterhoudt, K. C. 1987. Cadmium uptake and toxicity via voltage-sensitive calcium channels. J. Biol. Chem. 262: 16333-16337. [Medline]

17. Hinkle, P. M., Shanshala, E. D. 2nd. and Nelson, E. J. 1992. Measurement of intracellular cadmium with fluorescent dyes. Further evidence for the role of calcium channels in cadmium uptake. J. Biol. Chem. 267: 25553-25559. [Medline]

18. Jomova, K. and Valko, M. 2011. Advances in metal-induced oxidative stress and human disease. Toxicology 283: 65-87. [Medline] [CrossRef]

19. Kwan, C. Y. and Putney, J. W. Jr. 1990. Uptake and intracellular sequestration of divalent cations in resting and methacholinestimulated mouse lacrimal acinar cells. Dissociation by $\mathrm{Sr}^{2+}$ and $\mathrm{Ba}^{2+}$ of agonist-stimulated divalent cation entry from the refilling of the agonist-sensitive intracellular pool. J. Biol. Chem. 265: 678-684. [Medline]

20. Lynes, M. A., Kang, Y. J., Sensi, S. L., Perdrizet, G. A. and Hightower, L. E. 2007. Heavy metal ions in normal physiology, toxic stress, and cytoprotection. Ann. N. Y. Acad. Sci. 1113: 159-172. [Medline] [CrossRef]

21. Marchi, B., Burlando, B., Panfoli, I. and Viarengo, A. 2000. Interference of heavy metal cations with fluorescent $\mathrm{Ca}^{2+}$ probes does not affect $\mathrm{Ca}^{2+}$ measurements in living cells. Cell Calcium 28: 225-231. [Medline] [CrossRef]

22. Martin, J. L., Stork, C. J. and Li, Y. V. 2006. Determining zinc with commonly used calcium and zinc fluorescent indicators, a question on calcium signals. Cell Calcium 40: 393-402. [Medline] [CrossRef]

23. Marty, M. S. and Atchison, W. D. 1997. Pathways mediating $\mathrm{Ca}^{2+}$ entry in rat cerebellar granule cells following in vitro exposure to methyl mercury. Toxicol. Appl. Pharmacol. 147: 319-330. [Medline] [CrossRef]

24. Marchetti, C. 2013. Role of calcium channels in heavy metal toxicity. ISRN Toxicol. 2013: 184360 [CrossRef]. [Medline]

25. Nishimura, Y., Yamaguchi, J. Y., Kanada, A., Horimoto, K., Kanemaru, K., Satoh, M. and Oyama, Y. 2006. Increase in intracellular $\left.\mathrm{Cd}^{2+}\right)$ concentration of rat cerebellar granule neurons incubated with cadmium chloride: cadmium cytotoxicity under external $\mathrm{Ca}\left({ }^{2+}\right)$-free condition. Toxicol. In Vitro 20: 211-216. [Medline] [CrossRef]

26. Oyama, Y., Tomiyoshi, F., Ueno, S., Furukawa, K. and Chikahisa, L. 1994. Methylmercury-induced augmentation of oxidative metabolism in cerebellar neurons dissociated from the rats: its dependence on intracellular $\mathrm{Ca}^{2+}$. Brain Res. 660: 154-157.
[Medline] [CrossRef]

27. Peppiatt, C. M., Collins, T. J., Mackenzie, L., Conway, S. J., Holmes, A. B., Bootman, M. D., Berridge, M. J., Seo, J. T. and Roderick, H. L. 2003. 2-Aminoethoxydiphenyl borate (2APB) antagonises inositol 1,4,5-trisphosphate-induced calcium release, inhibits calcium pumps and has a use-dependent and slowly reversible action on store-operated calcium entry channels. Cell Calcium 34: 97-108. [Medline] [CrossRef]

28. Ramanathan, G. and Atchison, W. D. 2011. $\mathrm{Ca}^{2+}$ entry pathways in mouse spinal motor neurons in culture following in vitro exposure to methylmercury. Neurotoxicology 32: 742-750. [Medline] [CrossRef]

29. Sadiq, S., Ghazala, Z., Chowdhury, A. and Büsselberg, D. 2012. Metal toxicity at the synapse: presynaptic, postsynaptic, and long-term effects. J. Toxicol. 2012: 132671 [CrossRef]. [Medline]

30. Sarafian, T. A. 1993. Methyl mercury increases intracellular $\mathrm{Ca}^{2+}$ and inositol phosphate levels in cultured cerebellar granule neurons. J. Neurochem. 61: 648-657. [Medline] [CrossRef]

31. Sukumar, P. and Beech, D. J. 2010. Stimulation of TRPC5 cationic channels by low micromolar concentrations of lead ions $\left(\mathrm{Pb}^{2+}\right)$. Biochem. Biophys. Res. Commun. 393: 50-54. [Medline] [CrossRef]

32. Thévenod, F. 2010. Catch me if you can! Novel aspects of cadmium transport in mammalian cells. Biometals 23: 857-875. [Medline] [CrossRef]

33. Tomsig, J. L. and Suszkiw, J. B. 1990. $\mathrm{Pb}^{2(+)}$-induced secretion from bovine chromaffin cells: fura-2 as a probe for $\mathrm{Pb}^{2+} . A m . J$. Physiol. 259: C762-C768. [Medline]

34. Xie, L., Zheng, W., Xin, N., Xie, J. W., Wang, T. and Wang, Z. Y. 2012. Ebselen inhibits iron-induced tau phosphorylation by attenuating DMT1 up-regulation and cellular iron uptake. Neurochem. Int. 61: 334-340. [Medline] [CrossRef]

35. Xu, B., Chen, S., Luo, Y., Chen, Z., Liu, L., Zhou, H., Chen, W., Shen, T., Han, X., Chen, L. and Huang, S. 2011. Calcium signaling is involved in cadmium-induced neuronal apoptosis via induction of reactive oxygen species and activation of MAPK/ mTOR network. PLOS ONE 6: e19052 [CrossRef]. [Medline]

36. Xu, F., Farkas, S., Kortbeek, S., Zhang, F. X., Chen, L., Zamponi, G. W. and Syed, N. I. 2012. Mercury-induced toxicity of rat cortical neurons is mediated through N-Methyl-D-Aspartate receptors. Mol. Brain 5: 30 [CrossRef]. [Medline]

37. Xu, B., Xu, Z. F. and Deng, Y. 2009. Effect of manganese exposure on intracellular $\mathrm{Ca}^{2+}$ homeostasis and expression of NMDA receptor subunits in primary cultured neurons. Neurotoxicology 30: 941-949. [Medline] [CrossRef]

38. Xu, S. Z., Zeng, B., Daskoulidou, N., Chen, G. L., Atkin, S. L. and Lukhele, B. 2012. Activation of TRPC cationic channels by mercurial compounds confers the cytotoxicity of mercury exposure. Toxicol. Sci. 125: 56-68. [Medline] [CrossRef]

39. Yuan, Y. and Atchison, W. D. 2007. Methylmercury-induced increase of intracellular $\mathrm{Ca}^{2+}$ increases spontaneous synaptic current frequency in rat cerebellar slices. Mol. Pharmacol. 71: 1109-1121. [Medline] [CrossRef]

40. Yuan, Y., Jiang, C. Y., Xu, H., Sun, Y., Hu, F. F., Bian, J. C., Liu, X. Z., Gu, J. H. and Liu, Z. P. 2013. Cadmium-induced apoptosis in primary rat cerebral cortical neurons culture is mediated by a calcium signaling pathway. PLOS ONE 8: e64330 [CrossRef]. [Medline]

41. Zhivotovsky, B. and Orrenius, S. 2011. Calcium and cell death mechanisms: a perspective from the cell death community. Cell Calcium 50: 211-221. [Medline] [CrossRef] 